\title{
Cytological aspects of pleural, peritoneal and pericardial fluids from patients with systemic lupus erythematosus
}

\author{
B. NAYLOR \\ Department of Pathology, The University of Michigan, Ann Arbor, MI, USA
}

Accepted for publication 26 November 1991

NAYLOR B. (1992) Cytopathology 3, 1-8

Cytological aspects of pleural, peritoneal and pericardial fluids from patients with systemic lupus erythematosus

Serous effusions of nine of 33 patients with systemic lupus erythematosus contained lupus erythematosus (LE) cells, identifiable in Papanicolaou-stained smears, wet films stained with toluidine blue, and cell blocks stained with haematoxylin and eosin. Specimens in which LE cells were found contained at least a moderate number of polymorphonuclear neutrophilic leucocytes. Most specimens containing LE cells also contained cells that resembled LE cells (tart cells), which appeared to be small macrophages that had phagocytosed a nonhomogenized nucleus of a cell that had undergone degeneration. In 34 years of cytologic practice we have recognized LE cells in serous effusions only from patients who were already diagnosed as having systemic lupus erythematosus.

Keywords: serous effusions, cytology, systemic lupus erythematosus, lupus erythematosus cells

\section{INTRODUCTION}

Non-organ-specific autoimmune diseases are best exemplified by systemic lupus erythematosus (SLE), with its various autoimmune responses and clinical manifestations. Since the basic pathological changes of SLE-fibrinoid necrosis of connective tissue, vasculitis and a characteristic alteration of nuclear material—may take place in many different organs in any system of the body, its clinical manifestations are notoriously variable. Consequently, during the course of the disease a patient with SLE may develop inflammation of one or more serous membranes, resulting in pleural, peritoneal or pericardial effusion.

Correspondence: Dr B. Naylor, University Hospitals, Box 0054-Pathology, Ann Arbor, MI 48109-0054, USA. 


\section{B. Naylor}

The most notable of the autoantibodies found in excess in SLE are those against nuclear components, resulting in the formation of immunocomplexes that are believed to cause the nuclei of dead or injured cells to become denatured and homogenized. Such altered nuclear material, first recognized in histological specimens from patients with SLE, was originally

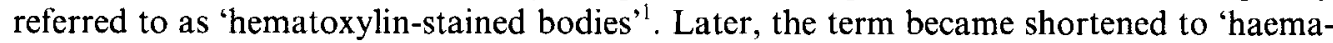
toxylin body', defined as a round, dense, homogeneous, cyanophilic body about the size of a neutrophilic leucocyte, probably consisting mainly of altered nuclear material with a small cytoplasmic component ${ }^{2}$.

When a haematoxylin body becomes phagocytosed, the phagocytic cell (usually a neutrophilic leucocyte, occasionally an eosinophilic leucocyte or a macrophage) with its engulfed contents is known as an a lupus erythematosus (LE) cell. For a full account of the serendipitous discovery of the LE cell (in bone marrow) and its morphology, the interested reader should consult the original article by Hargraves and colleagues ${ }^{3}$ and the subsequent reviews by Hargraves ${ }^{4,5}$.

Soon after its discovery in bone marrow, the LE cell was reported in peripheral blood ${ }^{6}$, and it has subsequently been found in pleural, peritoneal and pericardial fluids. Most of the welldocumented and illustrated examples of LE cells in serous fluids from patients with SLE were derived from pleural fluid ${ }^{7-23}$, with the next most frequently publised source being pericardial fluid $^{24-26}$ and the least common being peritoneal fluid ${ }^{27}$. Some of these publications also mentioned the other types of cells that were present in the effusions: various mixtures of leucocytes (of all types) and mesothelial cells. It is obvious that these other cells did not make any contribution to the diagnosis of SLE.

In all of the publications referred to above, the techniques used to prepare the specimens were those customarily used for routine cytological examination. None described incubating a specimen at $37^{\circ} \mathrm{C}$, which used to be part of the standard procedure for detecting LE cells in peripheral blood. Some of the illustrated LE cells were found in smears or wet films of the cell sediment obtained by centrifugation, whereas others were found in cell block preparations. Furthermore, the stains used were either the Papanicolaou stain, toluidine blue, a Romanowsky stain, or haematoxylin and eosin.

Since it is possible to find LE cells in pleural, peritoneal or pericardial fluids, it is appropriate to enquire as to the frequency with which patients with SLE develop such effusions. This information has been supplied by Dubois \& Wallace ${ }^{24}$ in a comprehensive cumulative review of the prevalence of clinical, biochemical, haematological and immunological manifestations of SLE in 1420 patients with the disease. At some stage of the disease, pleural effusion developed in 16-40\% of patients and peritoneal effusion in 9-11\%; pericarditis, with or without effusion, developed in $6-45 \%$. A cumulative review by the same authors showed that up to $3 \%$ of patients with SLE developed either pleural effusion or pericarditis as an initial manifestation of the disease ${ }^{24}$. Ascites as the presenting feature of SLE is less common, although a few cases have been reported ${ }^{28}$. Over the last 34 years we have examined 36 serous fluids from 33 patients known to have SLE. In every case the effusion was attributable to SLE or to one of its complications. We reviewed the cytological findings in these fluids to find out the prevalence of LE cells in the specimens, to observe the morphological features of LE cells, and to note any other cytological findings that might signify a patient had SLE. Undoubtedly, over the 34 years of our laboratory's existence we received serous fluids from other patients with SLE but were not made aware that these patients had the disease. Consequently, the fluids from these patients did not come under review; to detect these additional cases would have required us to review about 10000 medical records. 
Table 1. Serous fluids containing lupus erythematosus cells: cytological findings

\begin{tabular}{ll} 
No. of specimens ( 9 patients) & 9 \\
Hacmatoxylin bodies & 6 \\
Necrotic cells & 4 \\
Neutrophils: & \\
$\quad$ Moderate to abundant & 9 \\
Absent to few & 0 \\
Tart cells & 5 \\
\hline
\end{tabular}

\section{MATERIALS AND METHODS}

We re-examined the cytological preparations of 36 specimens of fluid from the 33 patients with serous effusions attributed to SLE. To verify the diagnosis of SLE, the medical records of all 33 patients were reviewed. These patients were identified either from our routine records, where a report had mentioned that LE cells were or were not seen, or from follow-up studies which revealed that certain serous effusions had been caused by SLE. In the former group we were aware that the patients had SLE when we first examined the fluids, whereas in the latter group we were not.

The serous fluids were sent to the cytopathology laboratory in a fresh, non-anticoagulated state. Any coagulum was removed, compressed to reduce its volume, fixed in formalin and processed as a piece of tissue to become part of a haematoxylin and eosin-stained cell block. The sediment obtained by centrifugation of the fluids was smeared, fixed while wet and stained by the Papanicolaou technique. We also prepared a toluidine blue-stained wet film of the sediment, a routine procedure in our laboratory. Any remaining sediment was solidified by a plasma-thrombin clot technique for preparing cell blocks, then sectioned and stained with haematoxylin and eosin.

In re-examining the cytological specimens, particular attention was paid to the degree of cellularity and the presence of the following: LE cells, cells that simulated LE cells (tart cells), naked background particles of homogenized nuclear material (haematoxylin bodies), necrotic cells and leucocytes. Differential cell counts were not performed on any of the specimens since it is not the custom of our laboratory to do this. We noted, however, the approximate proportions of the different types of leucocytes in each specimen.

\section{RESULTS}

A total of 36 specimens of serous fluid (29 pleural, five peritoneal, two pericardial), were examined from 33 patients ( 27 female, six male) who had been diagnosed on clinical and immunological grounds as having SLE. Their ages ranged from 5 to 62 years, with a mean of 33 years (female, 32; male, 38 ) and a median of 33 years (female, 32; male, 40 ).

In nine of the 33 patients, one or more specimens of serous fluid contained LE cells. Eight of the nine patients had pleural effusion and one had pericardial effusion. All of the patients with LE cells in their fluids were female. The presence of LE cells, haematoxylin bodies, necrotic cells, tart cells and neutrophil leucocytes in the specimens is summarized in Table 1. LE cells and haematoxylin bodies were found not only in routinely prepared Papanicolaou 

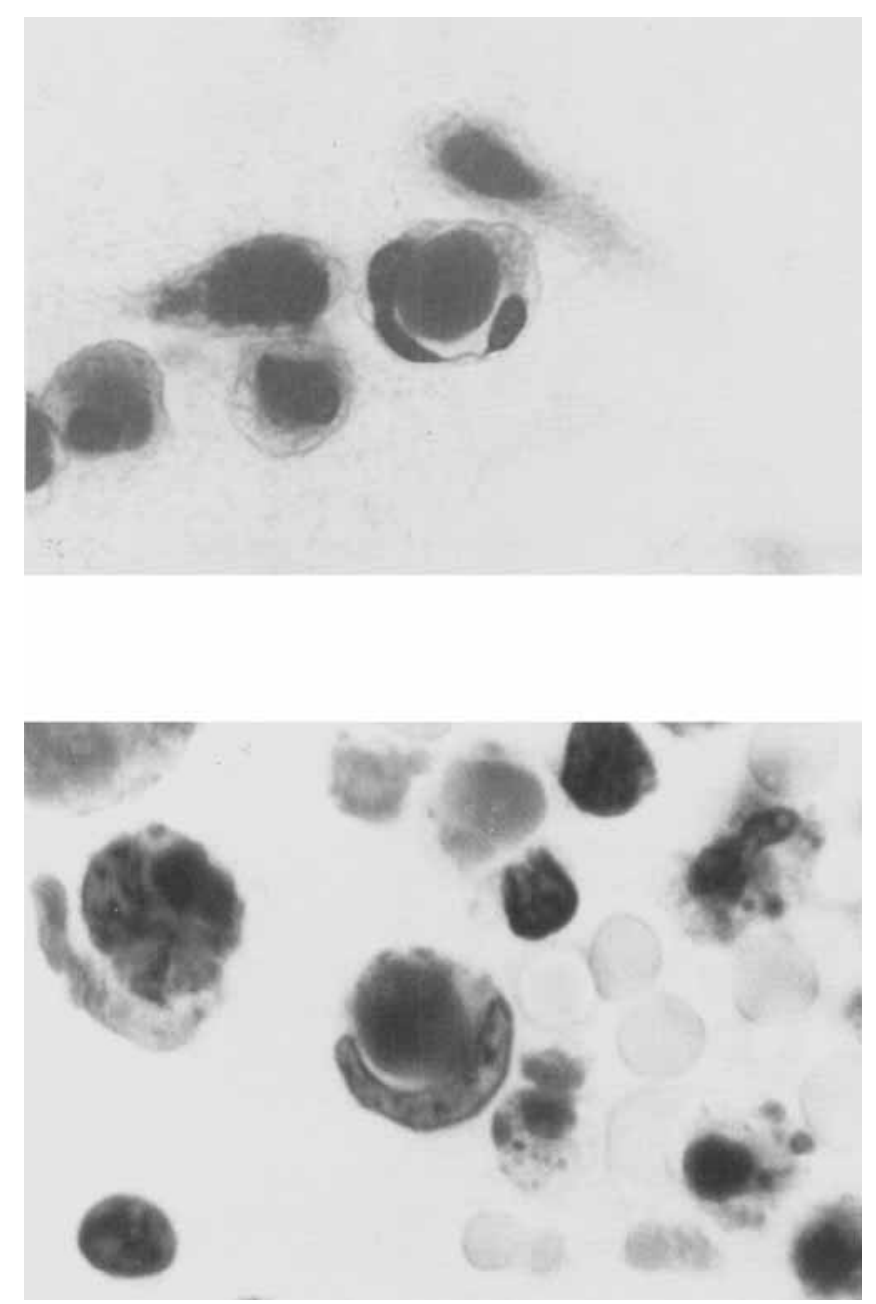

Figure 1. Smear of pericardial fluid. This illustrates a typical lupus erythematosus cell, consisting of a homogeneous nuclear mass in the cytoplasm of a neutrophilic leucocyte. Papanicolaou. $\times 1320$.
Figure 2. Stained wet film of pleural fluid. This illustrates a well-formed lupus erythematosus (LE) cell (centre). The background contains an incompletely developed LE cell (left of centre) and two haematoxylin bodies (above centre). Other cells are showing karyorrhexis. Toluidine blue. $\times 1320$.

stained smears (Figure 1) but also in toluidine blue-stained wet films (Figure 2) and cell block preparations.

Generally LE cells contained only a single cytoplasmic inclusion; occasionally two or three were present. Haematoxylin bodies were usually solitary, but occasionally were found in small clusters (Figure 3). In Papanicolaou-stained smears, the phagocytosed haematoxylin bodies of LE cells as well as non-phagocytosed haematoxylin bodies showed a variety of staining reactions: shades of grey, green, purple and blue. In toluidine blue-stained wet films the staining reaction of the phagocytosed and non-phagocytosed haematoxylin bodies was deep blue, and in cell blocks purple-pink to deep blue. In addition to LE cells and haematoxylin bodies, smears of four of the 36 specimens contained a background heavy in nuclear fragments and necrotic particles.

All serous fluids containing LE cells also contained readily found, though not necessarily predominating, neutrophilic leucocytes (Table 1). The background cytological picture 


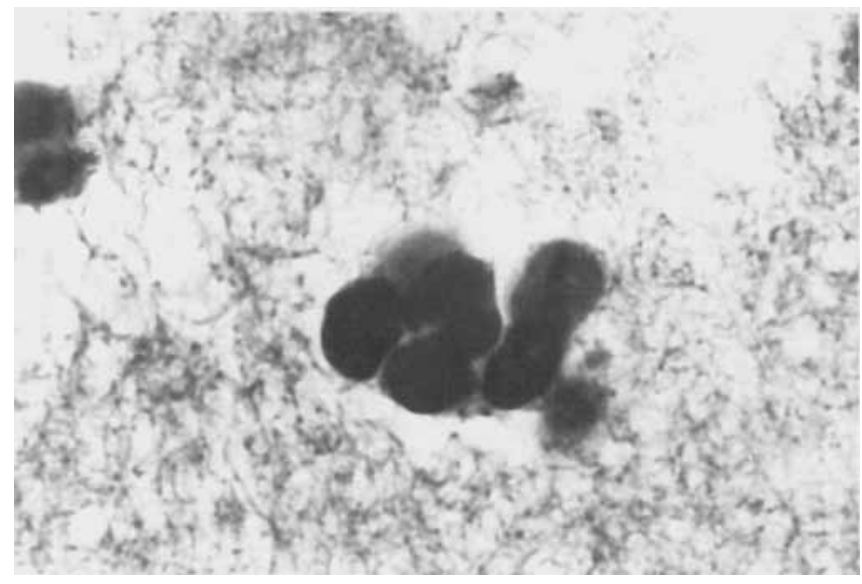

Figure 3. Cell block of pericardial fluid. A cluster of haematoxylin bodies in a background of fibrin. $H \& E$. $\times 1320$.

associated with LE cells was quite variable with respect to the number of lymphocytes, plasma cells, macrophages, neutrophilic leucocytes and mesothelial cells, confirming a similar observation made by Spriggs $\&$ Boddington ${ }^{21,22}$.

\section{DISCUSSION}

In our review of 36 serous effusions from 33 patients with SLE, we found LE cells in smears, cell blocks and stained wet films of nine patients, all women. In five of the nine cases, however, LE cells were not observed until we carried out a retrospective review of the specimens, which illustrates how easily they can be overlooked. LE cells may be quite readily found in a serous fluid (especially if they are being deliberately searched for) or they may be so few that several minutes of careful searching are required to find any. Having become more aware of the possibility of finding (or overlooking) LE cells in serous fluids, we expect the proportion of undetected examples to diminish.

A history of a patient having SLE may well facilitate the finding of LE cells. It is important, however, to be aware that a serous effusion may be the first clinical manifestation of SLE and that such a fluid may contain LE cells. Since SLE is found predominantly in women (only six of our 33 patients with SLE were male), and since many of the patients are young, with 11 of our 33 patients being below the age of 20 years, it is important to bear in mind that an unexplained serous effusion in a young person, especially a female, may be caused by SLE, and a deliberate search for LE cells in the fluid should be carried out.

During a search for LE cells one may also come across examples of cells referred to as 'tart cells'. In announcing their discovery of the LE cell, Hargraves and colleagues ${ }^{3}$ also described a cell in bone marrow aspirates morphologically similar to an LE cell; such cells may also be seen in serous fluids. They appear to be small macrophages that have phagocytosed a nonhomogeneous nucleus of another cell (Figure 4), presumably a cell that died and underwent cytolysis, thereby releasing a bare nucleus. Hargraves and colleagues' named these cells 'tart cells', not because they were likened to a form of pastry but because the last name of the patient in whose bone marrow they were first found in tremendous numbers was Tart. They have also been referred to as "pseudo-LE cells"22.

If they are looked for, tart cells can be found in most serous effusions, no matter what caused the effusion. The morphological difference between the inclusions in tart cells and 


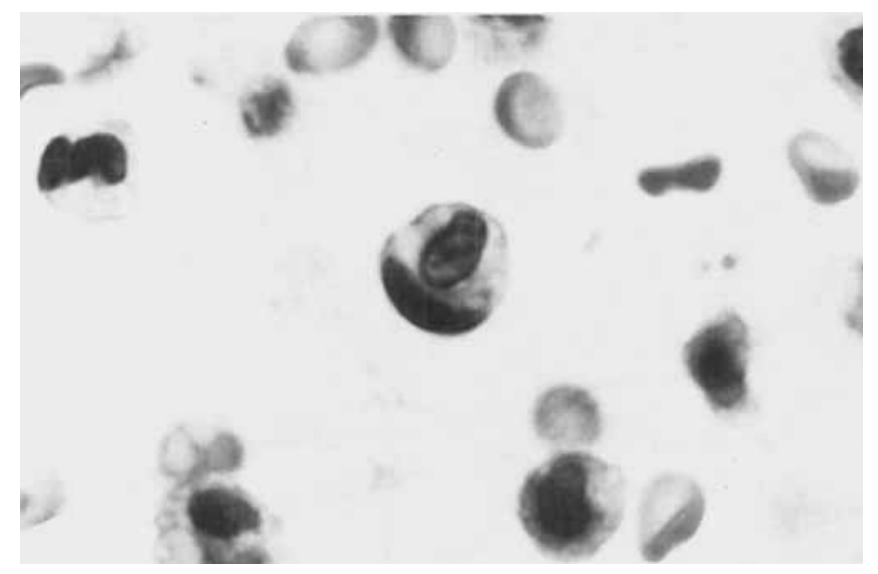

Figure 4. Cell block of pleural fluid. Tart cell. This patient had systemic lupus erythematosus, but lupus erythematosus cells were not found in the fluid. H\&E $\times 1320$. (Reproduced with permission from Naylor B. Pleural, peritoneal and pericardial fluids. In: Bibbo M, ed, Comprehensive Cytopathology. Philadelphia: WB Saunders, 1991; 571.)

those in LE cells have been described in detail by Hargraves ${ }^{4}$, and may be summarized by stating that in the former the phagocytosed nuclear material is not homogenous whereas in the latter the inclusions possess a smooth homogeneity or near homogeneity.

The formation of LE cells is generally regarded as an in vitro phenomenon, especially since serous fluids allowed to stand at room temperature may contain far more LE cells than the same fluid examined shortly after it was aspirated ${ }^{20,21}$. However, several authors ${ }^{20,21}$ found LE cells in pleural fluids very shortly after the fluids had been aspirated, which supports the idea that LE cells can develop in vivo. LE cells have been found in smears of blister fluid ${ }^{29}$ and in direct smears of blood obtained from constricted cyanotic fingers from patients with $\mathrm{SLE}^{30}$; in each of these situations the smears were made within seconds of the specimens being collected, which strongly suggests that LE cells can form in vivo.

Apart from the reported examples of LE cells in serous fluids of patients with SLE, there are reports of LE cells in pleural and peritoneal fluids from patients who developed an SLElike syndrome secondary to the taking of certain drugs ${ }^{31-35}$. In these drug-induced examples of the LE phenomenon, the LE cells were morphologically indistinguishable from those found in patients with non-drug-induced SLE and, as in some cases of SLE, they were sometimes found in the serous fluid before they were found in peripheral blood. Therefore, when LE cells are found in a serous fluid their presence should be reported, but unless a drug induced reaction can be ruled out one should not conclude that the patient has SLE. In 34 years of cytological practice, however, we have not come across an example of drug-induced LE cells in a serous effusion.

The cytological literature describes two examples of 'atypical' cells in pleural fluids from patients with SLE. The earlier of these reports ${ }^{36}$ depicted cells that were mistaken for neoplastic cells. It is obvious from the illustrations that the 'atypical' cells were hypertrophic mesothelial cells, a non-specific finding. Equally nonspecific were the 'atypical' cells depicted in a later publication ${ }^{37}$, which reported such cells in pleural fluids from 10 patients with SLE as being 'characteristic of systemic lupus erythematosus'. Again, the cells illustrated in the pleural fluids had the morphologic features of hypertrophic mesothelial cells. The authors also illustrated 'atypical' cells in a histologic section of inflamed pleura from one of the patients. The illustration depicted hypertrophic mesothelial cells accompanied by lymphoid and plasmacytoid cells in the pleural connective tissue. 
It would be most imprudent to allow the presence of hypertrophic mesothelial cells or plasmacytoid cells in serous fluids to point to or even suggest a diagnosis of SLE. Entirely non-specific and non-characteristic of SLE, they are commonly seen in serous fluids from patients with a wide variety of diseases. The only cell that has any diagnostic significance in SLE is the LE cell, with or without accompanying haematoxylin bodies.

The labour intensive LE test on peripheral blood is now obsolete, having been supplanted by a variety of other immunological tests of equal or superior reliability. Because of this, cytological examination of routinely processed serous fluids now offers the best opportunity for observing the cytological curiosity that is the LE cell.

\section{REFERENCES}

1 Gross $L$. The heart in atypical verrucous endocarditis (Libman-Sacks). In: AA Epstein, G Baehr, L Gross, AM Fishberg, MA Rothschild, I Strauss, eds, Contributions to the Medical Sciences in Honor of Dr Emmankel Lipman by his Pupils, Friends and Colleagues in Three Volumes, Volume 2. New York: The International Press, 1932; 2: 527-50.

2 Grishman E, Churg J. Ultrastructure of hematoxylin bodies in systemic lupus erythematosus. Arch Pathol Lab Med 1979; 103: 573-6.

3 Hargraves MM, Richmond H, Morton R. Presentation of two bone marrow elements: the 'tart' cell and the 'LE' cell. Proc Staff Meet Mayo Clin 1948: 23: $25-8$.

4 Hargraves MM. The LE cell phenomenon. $A d v$ Int Med 1954; 6: 133-60.

5 Hargraves MM. Discovery of the LE cell and its morphology. Mayo Clin Proc 1969; 44: 579-99.

6 Sundberg RD, Lick NB. 'LE' cells in the blood in acute disseminated lupus erythematosus. $J$ Invest Dermatol 1949; 12: 83-4.

7 Boccato P, Saran B, Pasini L, Briani G. Lupus erythematosus cells in pleural fluids. Acta Cytol 1978; 22: 441 .

8 Grubb C. Diagnostic Cytopathology. A Text and Colour Atlas. Edinburgh: Churchill Livingstone, $1988 ; 122$

9 Grunze H. Zytodiagnostik von Ergüssen serösen Korperhöhlen. In: Soost H-J, ed, Lehrbuch der klinischen Zytodiagnostik für medinischtechnische Assistentinnen, Zytologie-assistentinnen und Arzte. Stuttgart: Georg Thieme, 1974; 252-3.

10 Hidalgo C, Vladutiu AO. Lupus erythematosus cells in serum and pleural fluid of a patient with negative fluorescent antinuclear antibody test. $\mathrm{Am}$ J Clin Pathol 1987; 87: 660-2.

11 Keshegian AA. Lupus erythematosus cells in pleural fluid. Am J Clin Pathol 1978; 69: 570-1.

12 Kjeldsberg CR, Knight JA. Body Fluids. Laboratory Examination of Amniotic, Cerebrospinal, Seminal, Serous, and Synovial Fluids: A Textbook
Atlas, 2nd edn. Chicago: American Society of Clinical Pathologists, 1986; 86.

13 Koss LG. Diagnostic Cytology and Its Histopathologic Bases, 3rd edn. Philadelphia: JB Lippincott, $1979 ; 902$.

14 Lopes Cardozo P. Allas of Clinical Cytology. 'sHertogenbosch: Targa, 1976;260-1.

15 Makashir R, Jayaram G. Lupus erythematosus cells in pleural fluid. Diagn Cytopathol 1988; 4: 273-4.

16 Marsan C, Jagueux M, Leclerc J-P. Cytopathologie des épanchements des séreuses. Etude optique, histochimique, ultrastructurale. Encycl Méd Chir, Paris, Poumon, 12 1974, 6040 R-10, 4958.

17 Naylor B. Pleural, peritoneal and pericardial fluids. In: Bibbo M, ed, Comprehensive Cytopathology. Philadelphia; WB Saunders, 1991; 570-1.

18 Osamura RY, Shioya S, Handa K, Shimizu K. Lupus erythematosus cells in pleural fluid. Cytologic diagnosis in two patients. Acta Cytol 1977; 21: $215-17$.

19 Pandya MR, Agus B, Grady RF. In vivo LE phenomenon in pleural fluid. Arthritis Rheum 1976; 19: 962-3.

20 Reda MG, Baigelman W. Pleural effusion in systemic lupus erythematosus. Acta Cytol 1980; 24: $553-7$.

21 Spriggs AI, Boddington MM. The Cytology of Effusions and of Cerebrospinal Fluid, 2nd edn. London; William Heinemann, 1968; 9, 13, 15 , $82-3,107$.

22 Spriggs AI, Boddington MM. Atlas of Serous Fluid Cytopathology. A Guide to the Cells of Pleural, Pericardial, Peritoneal and Hydrocele Fluids. In: Gresham GA, ed, Current Histopathology Series, Volume 14. Dordrecht: Kluwer Academic Publishers, 1989; 45.

23 Van Doormal TAJ, Schreuder JThR. Uber die sogenannte Erythematodeszelle und deren Vorkommen in der Pleuraflüssigkeit bei einer an 'Lupus Erythematodes disseminatus acutus (subacutus)' leidenden Patientin. Dermatologica 1950; 101: $167-72$. 


\section{B. Naylor}

24 Dubois EL, Wallace DJ. Clinical and laboratory manifestations of systemic lupus erythematosus. In: Wallace DJ, Dubois EL, eds, Dubois' Lupus Erythematosus, 3rd ed. Philadelphia: Lea \& Febiger, 1987; 318-19, 342.

25 McGrew EA, Nanos S. The cytology of serous effusions. In: Keebler CM, Reagan JW, eds, $A$ Manual of Cytotechnology, 5th edn. Chicago: American Society of Clinical Pathologists, 1977; 199, 203.

26 Seaman AJ, Christerson JW. Demonstration of LE cells in pericardial fluid. Report of a case. JAMA 1952; 149: 145-7.

27 Metzger AL, Coyne M, Lee S, Kramer LS. In vivo LE cell formation in peritonitis due to SLE. $J$ Rheumatol 1974; 1: 130-3.

28 Jones PE, Rawcliffe P, White N, Segal AW. Painless ascites in systemic lupus erythematosus. $\mathrm{Br}$ Med J 1977; 1: 1513.

29 Watson JB, O'Leary PA, Hargraves MM. Neutrophils resembling LE cells in artificial blisters. Arch Dermatol 1951; 63: 328-33.

30 Sickley IF, Friedman IA, Feldhake C, Schwartz SO. In vivo demonstration of the lupus erythematosus phenomenon. J Lab Clin Med 1955; 46: $624 \cdots 7$.
31 Carel RS, Shapiro MS, Cordoba O, Taragan R, Gutman A. LE cells in pleural fiuid. Arthritis Rheum 1979; 22: 936 7 .

32 Carel RS, Shapiro MS, Shoham D, Gutman A Lupus erythematosus cells in pleural effusion: the initial manifestation of procainamide-induced lupus erythematosus. Chest 1977; 72: 670-2.

33 Carey RM, Coleman M, Feder A. Pericardial tamponade: a major presenting manifestation of hydralizine-induced lupus syndrome. $A m \mathrm{~J} \mathrm{Med}$ 1973; 54: 84-7.

34 Kaplan AI, Zakher F, Sabin S. Drug-induced lupus erythematosus with in vivo lupus erythematosus cells in pleural fluid. Chest 1978; 73: 875 6.

35 Young JA. Colour Atlas of Pulmonary Cytopathology. Oxford: Oxford University Press, 1985; 35-6.

36 Anikin BS, Myshentsiva LP. A case of systemic lupus erythematosus with atypical cells in the pleural exudate (in Russian). Ter Arkh Sep 1967; 39: $108-10$.

37 Kelley S, McGarry P, Hutson Y. Atypical cells in pleural fluid characteristic of systemic lupus erythematosus. Acta Cytol 1971; 15: 357-62. 